\title{
Structure-antimicrobial activity relationships of monoketone curcuminoids
}

\begin{abstract}
Background: Dental caries is a major public health concern worldwide. In this paper, we investigated the antimicrobial activity of three synthetic monoketone curcuminoids (MKCs) against a representative panel of cariogenic bacteria and examined some structure-antimicrobial activity relationships of MKCs.
\end{abstract}

Methods: MKCs 1 (curcumin A) and 2 were obtained by Claisen-Schmidt condensation in acidic conditions. Compounds $1 \mathrm{a}$ and $2 \mathrm{a}$ were obtained from 1 by catalytic hydrogenation. The minimum inhibitory concentration (MIC) values of $1 \mathrm{a}, 1 \mathrm{~b}$, and 2 were determined by using the broth micro dilution method in 96-well microplates. Chlorhexidine was used as positive control.

Results: Compound 2 afforded the lowest MIC values against Streptococcus mutans $(\mathrm{MIC}=50 \mu \mathrm{g} / \mathrm{mL})$ and Streptococcus mitis $(\mathrm{MIC}=50 \mu \mathrm{g} / \mathrm{mL})$, as well as moderate activity against $S$. sanguinis $(\mathrm{MIC}=100 \mu \mathrm{g} / \mathrm{mL}), S$. salivarus $(\mathrm{MIC}=200 \mu \mathrm{g} / \mathrm{mL})$. These results revealed that the antimicrobial activity of MKCs is enhaced by the presence of a hydroxy group at the aromatic rings, as well as the carbonyl group at $\mathrm{C} 1$ and the double bonds between $\mathrm{C} 2-\mathrm{C} 3$ and $\mathrm{C} 2$ '-C3'.

Conclusion: Compounds 1 and 2 displays promising antimicrobial activity against some cariogenic bacteria. Our results suggest that these compounds might be promising for the development of new oral care products.

Keywords: antibacterial activity, dental caries, monoketone curcuminoids, oral pathogens, Streptococcus mutans
Volume II Issue 6 - 2018

Tatiana MVieira,' Maria ALV Ambrosio, ${ }^{2}$ Carlos HG Martins, ${ }^{2}$ Antônio EM Crotti' 'Departamento de Química, Faculdade de Filosofia, Ciências e Letras de Ribeirão Preto, Universidade de São Paulo, Brazil ${ }^{2}$ Laboratorio de Pesquisa em Microbiologia Aplicada, Universidade de Franca, Brazil

Correspondence: Antônio EM Crotti, Departamento de Química, Faculdade de Filosofia, Ciências e Letras de Ribeirão Preto, Universidade de São Paulo, Av. Bandeirantes, 3900, Monte Alegre, CEP |4040-90| Ribeirão Preto, SP, Brazil, Tel +55 16 35I 5 3747, Fax 551635154838 , Email millercratti@ffclrp.usp.br

Received: October 22, 2018 | Published: November 15, 2018

\section{Abbreviations: MKCs, monoketone curcuminoids}

\section{Introduction}

Dental caries constitutes a major public health concern worldwide. This pathology is caused by acidogenic and aciduric bacteria, which produce a structurally and functionally organized biofilm (dental plaque)on the tooth surface. ${ }^{1}$ Streptococcus mutans is one of the most important colony-forming bacteria present in the bucal microbiota, stands out due its ability of producing substances that favor adhesion and the accumulation of other microorganisms, forming a resistant extracellular matrix that can destroy dental hard tissue. ${ }^{2}$ Brushing and flossing the teeth to remove dental plaque, as well as conducting periodic dental cleaning or prophylaxis are the most efficient ways to prevent caries. However, most people fail to maintain an efficient biofilm control through mechanical removal only, which has increased the use of oral products containing antimicrobial agents to diminish biofilm formation on the tooth surface. ${ }^{3}$ Although chlorhexidine is currently the most effective anti plaque agent, its use have been recommended by dentists only for short periods due to reversible local side effects. ${ }^{4}$

Recently, monoketone curcuminoids (MKCs), or 1,5-diarylpentadien-3-one derivatives, have been reported as promising compounds with respect to their antimicrobial activity against a panel of cariogenic bacteria, including S. mutans. ${ }^{5}$ Although some preliminary structure-relationships have been previously proposed, the effect of some important structure features on the antimicrobial activity was not evidenced. In this paper, we report on the antimicrobial activity of three MKCs derivatives against cariogenic bacteria aiming to better understand the structure-antimicrobial relationships among these compounds.

\section{Materials and methods}

\section{Synthesis of monoketone curcuminoids 1-2, 1a-1b}

Compounds 1 and 2 (Scheme 1) were obtained by aldol condensation in acidic conditions, as previously reported. ${ }^{6}$ Briefly, a mixture of acetone $(580 \mathrm{mg}, 10 \mathrm{mmol})$ and vanilin $(20 \mathrm{mmol})$ for compound 1 or 4-hidroxy-benzaldehyde $(20 \mathrm{mmol})$ for 2 was slowly added to acetic acid $(50 \mathrm{~mL})$ saturated with hydrogen chloride at $0 \mathrm{oC}$. The reaction mixture was stirred at room temperature for $24 \mathrm{~h}$. Next, the crude reaction mixture was poured into ice-cold water $(200 \mathrm{~mL})$ and then extracted with ethyl acetate $(3 \times 30 \mathrm{~mL})$. After drying the organic portion over $\mathrm{MgSO}_{4}$, filtration, and solvent removal under reduced pressure, the resulting solid was purified using silica gel flash column chromatography using hexane: ethyl acetate $1: 1(\mathrm{v} / \mathrm{v})$ (Figure 1). Compounds $1 \mathrm{a}$ and $1 \mathrm{~b}$ were obtained from 1 by catalytic hydrogenation. In this procedure, compound 1 dissolved in HPLC grade ethyl acetate was added to a high-pressure 1 reactor together with $\mathrm{Pd} / \mathrm{C}(10 \%)$ and kept at room temperature under stirring, $\mathrm{H}_{2}$ atmosphere, and pressure of $100 \mathrm{psi}$ for $18 \mathrm{~h} .{ }^{7}$ Chemical structures of compounds 1, 1a, 1b, and 2a were confirmed on the basis of NMR, IR, and MS analyses.

(1E,4E)-1,5-bis (4-hydroxy-3-methoxyphenyl)penta-1,4-dien3-one (1): Yield 21\%, orange powder. IR (KBr pellet) of $1\left(\mathrm{C}_{19} \mathrm{H}_{18} \mathrm{O}_{5}\right)$. $v / \mathrm{cm}^{-1}: 3411(\mathrm{vOH}), 3005(\mathrm{vCH}), 1714(\mathrm{vC}=\mathrm{O}), 1589(\mathrm{vC}=\mathrm{C}), 1093$ (vC-O). LRESI-MS $\left(\mathrm{m} / \mathrm{z}, \%\right.$ relative intensity): $327(100)[\mathrm{M}+\mathrm{H}]^{+}$. NMR ${ }^{1} \mathrm{H}\left(400 \mathrm{MHz}, \mathrm{CDCl}_{3}\right): \delta 3.95(6 \mathrm{H}, \mathrm{s}, \mathrm{H} 10=\mathrm{H} 10$ ') $6.93(2 \mathrm{H}$, $\left.d, J_{23=2,3}=15.8 \mathrm{~Hz}, \mathrm{H} 2=\mathrm{H} 2^{\prime}\right), 6.94\left(2 \mathrm{H}, d, J_{6,5=6,5^{\prime}}=8.2 \mathrm{~Hz}, \mathrm{H} 6=\mathrm{H} 6{ }^{\prime}\right)$, $7.11\left(2 \mathrm{H}, d, J_{9,5=9^{\prime}, 5}=1.4 \mathrm{~Hz}, \mathrm{H} 9=\mathrm{H} 9\right), 7.17\left({ }^{\prime} \mathrm{H}, d d, J_{5,6=5,6}=8.2\right.$, $\left.J_{5,9=5^{\prime}, 9}=1.4 \mathrm{~Hz}, \mathrm{H} 5=\mathrm{H} 5^{\prime}\right), 7.67\left(2 \mathrm{H}, d, J_{3,2=3^{\prime}, 2^{2}}=15.8 \mathrm{~Hz}, \mathrm{H}^{\prime}=\mathrm{H} 3{ }^{\prime}\right)$, $7.67\left(2 \mathrm{H}, d, J_{3,2=3}, 2=15.8 \mathrm{~Hz}, \mathrm{H} 3=\mathrm{H} 3{ }^{\prime}\right) .{ }^{13} \mathrm{C}\left(100 \mathrm{MHz}, \mathrm{CDCl}_{3}\right): \delta 56.2$ 
$\left(\mathrm{CH}_{3}, \mathrm{C} 10=\mathrm{C}^{\prime} 0^{\prime}\right), 109.8\left(\mathrm{CH}, \mathrm{C} 9=\mathrm{C}^{\prime}\right.$ ') $, 115.0\left(\mathrm{CH}, \mathrm{C} 6=\mathrm{C}^{\prime}\right), 123.4$ $\left(\mathrm{CH}, \mathrm{C} 5=\mathrm{C} 5\right.$ ') $123.5\left(\mathrm{CH}, \mathrm{C} 2=\mathrm{C} 2\right.$ ') $, 127.6\left(\mathrm{C}, \mathrm{C} 4=\mathrm{C} 4{ }^{\prime}\right), 143.3(\mathrm{CH}$, C3=C3'), $146.9\left(\mathrm{C}, \mathrm{C} 7=\mathrm{C}^{\prime}\right.$ ') $189.2(\mathrm{C}=\mathrm{O}, \mathrm{C} 1)$.

1,5-bis(4-hydroxy-3-methoxyphenyl)pentan-3-one (1a): Yield $37 \%$, white powder. IR ( $\mathrm{KBr}$ pellet) of $1 \mathbf{a}\left(\mathrm{C}_{19} \mathrm{H}_{22} \mathrm{O}_{5}\right) \cdot v_{\text {max }} / \mathrm{cm}^{-1}: 3520$ (v-OH), $2925\left(v_{\mathrm{sp}}{ }^{2}-\mathrm{H}\right), 1701(\mathrm{vC}=\mathrm{O}), 2999(v \mathrm{C}-\mathrm{H}), 1232(v \mathrm{C}-\mathrm{O})$. LRESI-MS ( $\mathrm{m} / \mathrm{z}, \%$ relative intensity): 331 (100) $[\mathrm{M}+\mathrm{H}]^{+}$. NMR ${ }^{1} \mathrm{H}$
(400 MHz, $\left.\mathrm{CDCl}_{3}\right): \delta 2.66\left(4 \mathrm{H}, t, J_{2,3=2^{\prime}, 3^{\prime}}=7.4 \mathrm{~Hz}, \mathrm{H} 2=\mathrm{H} 2\right.$ '), 2.81

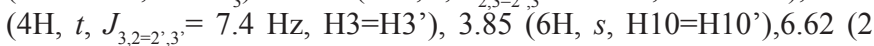
$\left.\mathrm{H}, d, J_{95: 9,5^{,},=1.9 \mathrm{~Hz}, \mathrm{H} 9=\mathrm{H} 9}{ }^{\prime}\right), 6.65\left(2 \mathrm{H}, d d, J_{5,65^{5}, 6^{\prime}}=7.9 \mathrm{~Hz}\right.$ and $\left.J_{5,9 ; 5,9}=1.9 \mathrm{~Hz}, \mathrm{H} 5=\mathrm{H} 5^{\prime}\right), 6.60\left(2 \mathrm{H}, \mathrm{d}, J_{6,5 ; 6,5},=7.9, \mathrm{~Hz}, \mathrm{H} 6=\mathrm{H} 6{ }^{\prime}\right) \cdot{ }^{13} \mathrm{C}$ $\left(100 \mathrm{MHz} \mathrm{CDCl}_{3}\right): \delta 29.6\left(\mathrm{CH}_{2} \mathrm{C} 3=\mathrm{C}^{\prime}{ }^{\prime}\right), 45.0\left(\mathrm{CH}_{2}, \mathrm{C} 2=\mathrm{C}^{\prime}\right), 55.9$ $\left(\mathrm{CH}_{3}, \mathrm{C} 10=\mathrm{C} 10 '\right), 111.1(\mathrm{CH}, \mathrm{C} 9=\mathrm{C} 9 '), 114.4\left(\mathrm{CH}, \mathrm{C} 6=\mathrm{C} 6{ }^{\prime}\right), 120.8$ $(\mathrm{CH}, \mathrm{C} 5=\mathrm{C} 5$ ') $133.0(\mathrm{C}, \mathrm{C} 4=\mathrm{C} 4$ '), $144.0(\mathrm{C}, \mathrm{C} 7=\mathrm{C} 7$ '), $146.6(\mathrm{C}$, $\left.\mathrm{C} 8=\mathrm{C}^{\prime}\right), 209.7(\mathrm{C}=\mathrm{O}, \mathrm{C} 1)$.

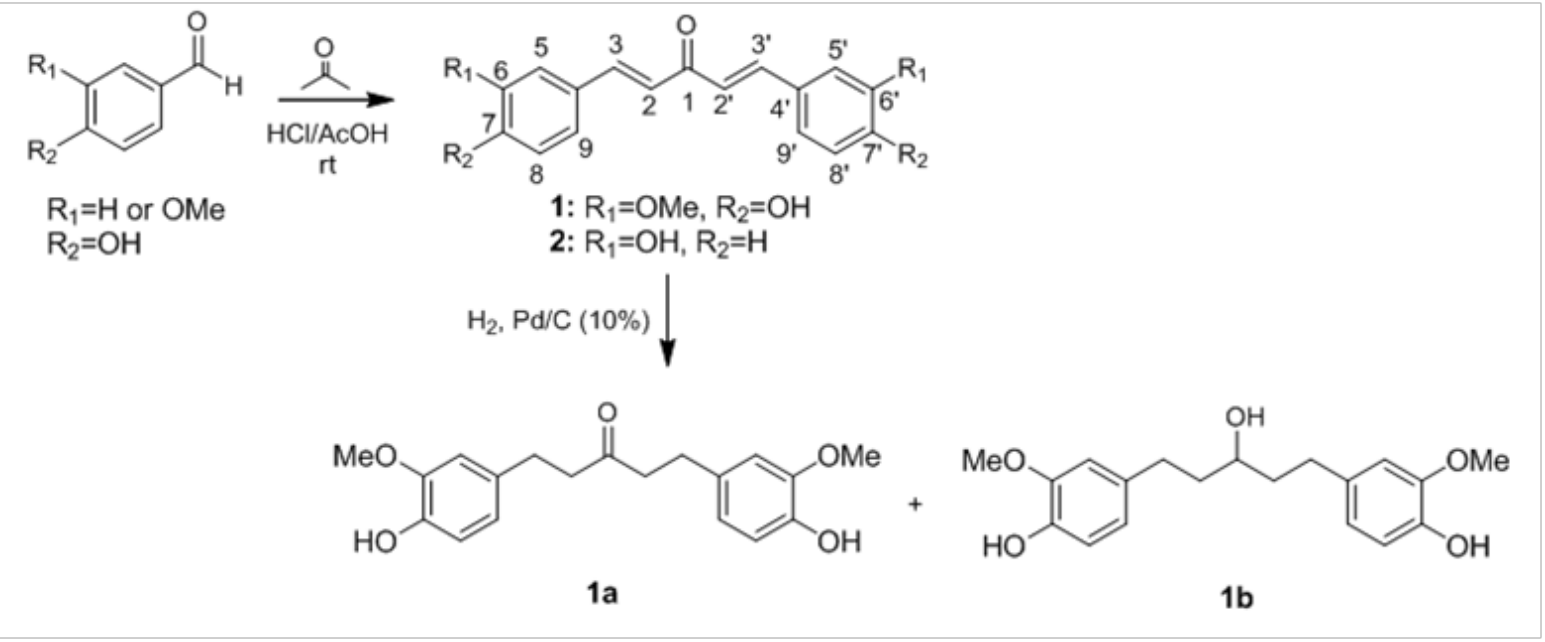

Figure 1 Reaction conditions for the synthesis of compounds $\mathbf{1 ,} \mathbf{2}$ and $\mathbf{1 a}-1 \mathbf{b}$ using aromatic aldehydes and acetone, r.t., and catalytic hydrogenation with $\mathrm{H}^{2}$, $\mathrm{Pd} / \mathrm{C}(10 \%), 100 \mathrm{psi}$, r.t.

4,4'-(3-hydroxypentane-1,5-diyl)bis(2-methoxyphenol) (1b):35.3\% Yield, white powder. IR (KBr pellet) of $\mathbf{1 b}\left(\mathrm{C}_{19} \mathrm{H}_{24} \mathrm{O}_{5}\right) \cdot v_{\max }$ ' $\mathrm{cm}^{-1}$ :3409 (vOH), $2913\left(\mathrm{vC}_{\mathrm{sp}}{ }^{2}-\mathrm{H}\right), 1513(\mathrm{vC}-\mathrm{O}), 2848(\mathrm{vC}-\mathrm{H}), 1240$ (vC-O). LRESI-MS $\left(\mathrm{m} / \mathrm{z}, \%\right.$ relative intensity): $333(100)[\mathrm{M}+\mathrm{H}]^{+}$. $\mathrm{NMR}{ }^{1} \mathrm{H}\left(400 \mathrm{MHz}, \mathrm{CDCl}_{3}\right): \delta 1.74\left(2 \mathrm{H}, d d d d, J_{2 a, 2 b ; 2 a^{\prime}, 2 b^{\prime}}=13.8 \mathrm{~Hz}\right.$, $\left.J_{2 a, 3 b ; 2 a^{\prime}, 3 b^{\prime}}=9.5 \mathrm{~Hz}, J_{2 a, 1 ; 2 a^{\prime}, 1}=7.7 \mathrm{~Hz}, J_{2 a, 3 a ; 2 a^{\prime}, 3 a^{\prime}}=6.0 \mathrm{~Hz}, \mathrm{H} 2 \mathrm{a}, 2 \mathrm{a}^{\prime}\right), 1.80(2$ $\mathrm{H}, \stackrel{d d d d}{d}, J_{2 b, 2 a=2 b ; 2 a}=13.8 \mathrm{~Hz}, J_{2 b, 3 a=2 b^{\prime}, 3 a^{\prime}}=9.4 \mathrm{~Hz}, J_{2 b, 3 b=2 b^{\prime}, 3 b^{\prime}}=6.8 \mathrm{~Hz}$, $\left.J_{2 b, 1=2 b^{\prime}, 1}=4.5 \mathrm{~Hz}, \quad \mathrm{H} 2 \mathrm{~b}, 2 \mathrm{~b}^{\prime}\right), 2.61\left(2 \mathrm{H}, \quad d d d, J_{3 b, 3 a=3 b^{\prime}, 3 a^{\prime}}=13.8 \mathrm{~Hz}\right.$, $\left.J_{3 b, 2 a=3 b^{\prime}, 2 a}=9.3 \mathrm{~Hz}, J_{3 b, 2 b=3 b^{\prime}, 2 b^{\prime}}=6.8 \mathrm{~Hz}, \mathrm{H} 3 \mathrm{~b}, 3 \mathrm{~b}^{\prime}\right), 2.71(2 \mathrm{H}, d d d$, $\left.J_{3 a, 3 b=3 a^{\prime}, 3 b^{\prime}}^{3 b}=13.8 \mathrm{~Hz}, J_{3 a, 2 b=3 a^{\prime}, 2 b^{\prime}}=9.2 \mathrm{~Hz}, J_{3 a, 2 a=3 a^{\prime}, 2 a^{\prime}}=6.5 \mathrm{~Hz}, \mathrm{H3a}, 3 \mathrm{a}^{\prime}\right)$, $3.67\left(1 \mathrm{H}, d t, J_{1,2 a=1^{\prime}, 2 a^{\prime}}=7.7 \mathrm{~Hz}, J_{1,2 b=1^{\prime}, 2 b^{\prime}}=4.5 \mathrm{~Hz}, \mathrm{H1}\right), 3.84(6 \mathrm{H}, s$, $\left.\mathrm{H} 10=\mathrm{H} 10^{\prime}\right), 3.68\left(2 \mathrm{H}, d d, J_{5,65^{\prime}, 6^{\prime}}=8.0 \mathrm{~Hz}\right.$ and $\left.J_{5,95^{\prime}, 9}=1.8 \mathrm{~Hz}, \mathrm{H} 5=\mathrm{H} 5^{\prime}\right)$, $6.64\left(2 \mathrm{H}, d, J_{9,5: 9^{\prime}, 5}=1.8 \mathrm{~Hz}, \mathrm{H}^{\prime}=\mathrm{H} 9^{\prime}\right), 6.82\left(2 \mathrm{H}, d, J_{6,5 ; 6,5}=8.0 \mathrm{~Hz}\right.$, $\mathrm{H} 6=\mathrm{H} 6$ ' $) .{ }^{13} \mathrm{C}\left(100 \mathrm{MHz}, \mathrm{CDCl}_{3}\right): \delta 32.0\left(\mathrm{CH}_{2} \mathrm{C} 3=\mathrm{C} 3\right.$ '), $39.3\left(\mathrm{CH}_{2}\right.$, $\mathrm{C} 2=\mathrm{C} 2$ '), $56.1\left(\mathrm{CH}_{3}, \mathrm{C} 10=\mathrm{C} 10^{\prime}\right), 71.0\left(\mathrm{CH},{ }^{2} \mathrm{C} 1=\mathrm{C} 1^{\prime}\right), 111.1(\mathrm{CH}$, $\left.\mathrm{C} 9=\mathrm{C}^{\prime}\right), 114.4(\mathrm{CH}, \mathrm{C} 6=\mathrm{C} 6$ ') $120.9(\mathrm{CH}, \mathrm{C} 5=\mathrm{C} 5$ ') $134.0(\mathrm{C}$, $\mathrm{C} 4=\mathrm{C}^{\prime}$ '), 143.7 (C, $\mathrm{C} 7=\mathrm{C}^{\prime}$ '), 146.5 (C, C8=C8').

(1E,4E)-1,5-bis(4-hydroxyphenyl)penta-1,4-dien-3-one (2): Yield $43.8 \%$, orange powder. IR ( $\mathrm{KBr}$ pellet) of $2\left(\mathrm{C}_{17} \mathrm{H}_{14} \mathrm{O}_{3}\right) \cdot v_{\max } /$ $\mathrm{cm}^{-1}: 3325(\mathrm{vOH}), 2924\left(\mathrm{vC}_{\mathrm{sp}}{ }^{2}-\mathrm{H}\right), 1596(\mathrm{vC}=\mathrm{O}), 1511(\mathrm{vC}=\mathrm{C})$. LRESI-MS: $\left(\mathrm{m} / \mathrm{z}, \%\right.$ relative intensity): $267(100)[\mathrm{M}+\mathrm{H}]^{+}$. NMR ${ }^{1} \mathrm{H}$ $\left(400 \mathrm{MHz}, \mathrm{CDCl}_{3}\right): \delta 6.90\left(4 \mathrm{H}, d, J_{6,5: 6^{\prime}, 5^{\prime}}=8.5 \mathrm{~Hz}, \mathrm{H} 6=\mathrm{H} 6{ }^{\prime}=\mathrm{H} 8=\mathrm{H} 8^{\prime}\right)$, $7.10\left(2 \mathrm{H}, d, J_{2,3=2^{\prime}, 3^{\prime}}=16.0 \mathrm{~Hz}, \mathrm{H} 2=\mathrm{H} 2^{\prime}\right), 7.60\left(4 \mathrm{H}, d, J_{5,6=5,6^{\prime}}=8.5 \mathrm{~Hz}\right.$, $\left.\mathrm{H} 5=\mathrm{H} 5^{\prime}=\mathrm{H} 9=\mathrm{H} 9^{\prime}\right), \quad 7.70 \quad\left(2 \mathrm{H}, d, J_{3,2=3^{\prime}, 2^{\prime}}=16.0 \mathrm{~Hz}, \quad{ }^{\mathrm{H}} 3=\mathrm{H} 3{ }^{\prime}\right) .{ }^{13} \mathrm{C}$ $\left(100 \mathrm{MHz}, \mathrm{CDCl}_{3}\right): \delta 116.6\left(\mathrm{CH}, \mathrm{C} 5^{2}=\mathrm{C}^{\prime}=\mathrm{C} 9=\mathrm{C} 9^{\prime}\right), 123.6(\mathrm{CH}$, $\left.\mathrm{C} 2=\mathrm{C} 2{ }^{\prime}\right), 127.4\left(\mathrm{C}, \mathrm{C} 4=\mathrm{C} 4\right.$ '), $130.9\left(\mathrm{CH}, \mathrm{C} 6=\mathrm{C} 6{ }^{\prime}=\mathrm{C} 8=\mathrm{C} 8\right.$ '), 142.9 $(\mathrm{CH}, \mathrm{C} 3=\mathrm{C} 3$ '), $160.5(\mathrm{C}, \mathrm{C} 7=\mathrm{C} 7$ '), $188.8(\mathrm{C}=\mathrm{O}, \mathrm{C} 1)$.

\section{Antimicrobial assays}

The in vitro antimicrobial activity of compounds $\mathbf{1 - 2}, \mathbf{1 a - 1} \mathbf{b}$ was evaluated on the basis of their minimum inhibitory concentration
(MIC) values, according to the previously reported methodology. ${ }^{8}$ Briefly, Streptococcus mitis (ATCC 49456), Streptococcus mutans (ATCC 25175), Streptococcus salivarius (ATCC 25975), Streptococcus sobrinus (ATCC 33478), Streptococcus sanguinis (ATCC 10556), Lactobacillus casei (ATCC 11578), and Enterococcus faecalis (ATCC 4082) were tested by the broth micro dilution method, in 96-well micro plates. Colonies of the selected bacteria were cultured in blood agar (Difco Labs, Detroit, MI, USA) at $37{ }^{\circ} \mathrm{C}$ for $24 \mathrm{~h}$. Next, the inoculum quantity was standardized to match 0.5 in the McFarland scale $\left(1.5 \times 10^{8} \mathrm{CFU} / \mathrm{mL}\right)$ using a spectrophotometer Femto (São Paulo, Brazil) at $625 \mathrm{~nm}$. The microorganism suspensions were diluted to a final concentration of $5 \times 10^{5} \mathrm{CFU} / \mathrm{mL}$. Compounds $\mathbf{1}, \mathbf{1 a}, \mathbf{1 b}$, and $\mathbf{2}$ were dissolved in tryptic soy broth (TSB, Difco) and dimethylsulfoxide (DMSO) (Merck, Darmstadt, Germany) to achieve final concentrations between 0.195 and $400 \mu \mathrm{g} / \mathrm{mL}$. Inoculated micro plate wells containing TSB (1:5 v/v and 100\%) and DMSO (1\%) were used as negative control. To ensure medium sterility, anon-inoculated well was also added. Chlorhexidine dihydrochloride (Sigma-Aldrich, St. Louis), which was used as positive control was dissolved in TSB and tested at concentrations from 0.115 to $59.0 \mu \mathrm{g} / \mathrm{mL}$. The microplates were then sealed with plastic film and incubated for $24 \mathrm{~h}$ at $37^{\circ} \mathrm{C}$. Next, $30 \mu \mathrm{L}$ of revealing $0.02 \%$ resazurin (Sigma-Aldrich, St. Louis) was added to each microplate well, to indicate the microbial viability. We conducted the experiments in three replicates for each microorganism. The MIC values were assessed on the basis of the MKCs capacity to prevent the resazurin color solution from changing.

\section{Results and discussion}

In a previous work, we reported the antimicrobial activity of twenty-five monoketone curcuminoids, including curcumin A (1), which was demonstrated to be more effective than curcumin against $S$. 
mutans and S. mitis. However, some important structure-antimicrobial relationship structure of MKCs were not clear. Here, we investigated the antimicrobial activity of three MKCs against a panel of cariogenic bacterial strains on the basis of their minimum inhibitory concentration (MIC) values.

Classification of the antibacterial activity was based on MIC values, in this way, MIC values lower than $100 \mu \mathrm{g} / \mathrm{mL}$, between $100<\mathrm{MIC}<500 \mathrm{mg} / \mathrm{mL}$ or between $500<\mathrm{MIC}<1000 \mu \mathrm{g} / \mathrm{mL}$ and higher than $1000 \mathrm{mg} / \mathrm{mL}$ correspond to promising, moderate, weak and inactive activities, respectively. ${ }^{9-12}$ In this way, according to these criteria, compounds $\mathbf{1}$ and $\mathbf{2}$ displayed the lowest MIC values against $S$. mutans $(\mathrm{MIC}=50 \mu \mathrm{g} / \mathrm{mL})$ and $S$. mitis $(\mathrm{MIC}=50 \mu \mathrm{g} / \mathrm{mL})$, as well as moderate activity against $S$. sanguinis $(\mathrm{MIC}=100 \mu \mathrm{g} / \mathrm{mL})$, $S$. salivarus $(\mathrm{MIC}=200 \mu \mathrm{g} / \mathrm{mL}$ ) and compound $\mathbf{1}$ was also active against $L$. casei $(\mathrm{MIC}=100 \mu \mathrm{g} / \mathrm{mL})$. Compound 2 also had promising activity for $L$. casei $(\mathrm{MIC}=25 \mu \mathrm{g} / \mathrm{mL}$ ) and moderate activity against S. sobrinus ( $\mathrm{MIC}=200 \mu \mathrm{g} / \mathrm{mL}$ ). Moreover, the compounds $\mathbf{1 b}$ also displayed moderate active against $S$. mutans $((\mathrm{MIC}=200 \mu \mathrm{g} / \mathrm{mL}), S$. mitis $(\mathrm{MIC}=100 \mu \mathrm{g} / \mathrm{mL})$, S. sanguinis $(\mathrm{MIC}=200 \mu \mathrm{g} / \mathrm{mL})$ and L. casei $(\mathrm{MIC}=200 \mu \mathrm{g} / \mathrm{mL})$. The activity of compound $\mathbf{1}$ and $\mathbf{2}$ against $S$. mutans is a note worthy result because natural compounds capable to inhibit this primary causative agents of dental cariesare still scarce. ${ }^{2}$ None of the tested MKCs was significantly active against Enterococcus faecalis (Table 1).

Table 1 Minimum inhibitory concentration (MIC) values $[\mu \mathrm{g} / \mathrm{mL}]$ of the monoketone curcuminoids against selected cariogenic bacteria

\begin{tabular}{llllll}
\hline Microorganism & $\mathbf{1}$ & $\mathbf{1 a}$ & $\mathbf{1 b}$ & $\mathbf{2}$ & Positive control \\
\hline Streptococcus mutans(ATCC 25175) & 50 & $>400$ & 200 & 50 & $0.92^{\mathrm{a}}$ \\
Streptococcus mitis(ATCC 49456) & 50 & 400 & 100 & 50 & $1.84^{\mathrm{a}}$ \\
Streptococcus salivarius(ATCC 25975) & 200 & $>400$ & $>400$ & 200 & $1.84^{\mathrm{a}}$ \\
Streptococcus sanguinis(ATCC 10556) & 100 & 400 & 200 & 100 & $0.92^{\mathrm{a}}$ \\
Streptococcus sobrinus(ATCC 33478) & 400 & 400 & 400 & 200 & $0.92^{\mathrm{b}}$ \\
Enterococcus faecalis(ATCC 4082) & $>400$ & $>400$ & $>400$ & 400 & $7.37^{\mathrm{a}}$ \\
Lactobacillus casei(ATCC 11578) & 100 & 400 & 200 & 25 & $0,92^{\mathrm{a}}$ \\
\hline
\end{tabular}

${ }^{a}$ chlorhexidine duhydrochloride

According to previous reports, MKCs bearing a double bond between $\mathrm{C} 2$ and $\mathrm{C} 3$, and between $\mathrm{C} 2$ 'and $\mathrm{C} 3$ ' were inactive against the tested microorganisms in the range of concentrations tested, except for compound 1 (curcumin A). ${ }^{5}$ These results led us to suspect that the higher activity observed for curcumin A could be related to the simultaneous presence of methoxy and hydroxy groups in the aromatic ring, since compounds displaying one, two or three methoxy groups at the aromatic ring were inactive. ${ }^{5}$ To verify this hypothesis, we synthesized the curcumin A derivatives $\mathbf{1 a}$ and $\mathbf{1 b}$ and the hydroxy curcuminoid $\mathbf{2}$ and evaluated their antimicrobial activity against cariogenic bacteria. Comparison between the MIC values of curcumin A (1) and compounds $\mathbf{1 a}$ and $\mathbf{1 b}$ revealed that absence of the double bond between reduction of the carbonyl group at $\mathrm{C} 1 \mathrm{and} /$ or the double bond between $\mathrm{C} 2$ and $\mathrm{C} 3 / \mathrm{C} 2$ '-C3' caused a significative reduction in the antimicrobial activity. In addition, it was observed that compound 2 , which does not have a methoxy group in its structure displayed antimicrobial activity very similar to that of compound $\mathbf{1}$. Compound 2 was more activity than curcumin A against $S$. sobrinus $(\mathrm{MIC}=200 \mu \mathrm{g} / \mathrm{mL}$ ) and L. casei $(\mathrm{MIC}=25 \mu \mathrm{g} / \mathrm{mL})$. These results revealed that the hydroxyl group at the aromatic ring plays a key role for the antimicrobial activity, and its presence is more important for this activity than the methoxyl group.

Data obtained from the present study, in combination with those previously reported, revealed that the carbonyl group at $\mathrm{C} 1$ and the double bonds between $\mathrm{C} 2$ and $\mathrm{C} 3$ are important structure features for the antimicrobial activities of MKCs. However, the nature of the substituent at the aromatic rings plays an important role in this activity. Among the tested compounds, compounds displaying a hydroxyl group (1 and 2) were much more active than those with methoxyl, bromine, chlorine, and methyl groups. ${ }^{5}$

\section{Conclusion}

Compounds $\mathbf{1}$ and $\mathbf{2}$ display promising antimicrobial activity against Streptococcus mutans, which is one of the main causative microorganism of dental caries. The hydroxyl group attached to the aromatic rings, as well as the double bond between $\mathrm{C} 2-\mathrm{C} 3$ and $\mathrm{C} 2 \mathrm{C} 3$, and the carbonyl group at $\mathrm{C} 1$, are the most important structure features for the antimicrobial activity. Taken together, these results suggest that these compounds might be promising for the development of new oral care products.

\section{Acknowledgements}

The authors thank the Brazilian foundations FAPESP (Proc. FAPESP 2016/19272-9 and 2013/20094-0) for the financial support and fellowships.

\section{Conflict of interest}

The authors declare no conflict of interest.

\section{References}

1. Chandki RBR, Banthia P. Biofilms: a microbial home. J Indian Soc Periodontol. 2011;15(2):111-114.

2. Arweiler LNNB. The Oral Microbiota. Adv Exp Med Biol. 2016;902:4560.

3. Marín M, Figuero M, González I, et al. Comparison of the detection of periodontal pathogens in bacteraemia after tooth brushing by culture and molecular techniques. Med Oral Patol Oral Cir Bucal. 2016;21(3):e276-284. 
4. Choo A, Delac DM Messer LB. Oral hygiene measures and promotion review and considerations. Aust Dent J. 2001;46(3):166-173.

5. Vieira TM, dos Santos IA, Silva TS, et al. Antimicrobial activity of monoketone curcuminoids against cariogenic bacteria. Chem Biodivers. 2018;15(8):e1800216.

6. Kumari N, Kulkarni AA, Lin X, et al. Inhibition of HIV-1 by curcumin A, a novel curcumin analog. Drug Des Devel Ther. 9:5051-5060.

7. Anand P, Kunnumakkara AB, Newman RA, et al. Bioavailability of curcumin: problems and promises reviews. Mol Pharm. 2007;4(6):807818.

8. Clinical and Laboratory Standards Institute. Methods for dilution antimicrobial susceptibility tests for bacteria that grow aerobically; approved standard, $9^{\text {th }}$ edn, 2012;32(2):M07-A9.

9. Karpinski T, Szkaradkiewicz A. Microbiology of dental caries. J Biol Earth Sci. 2013;3(1):21-24.

10. Gibbons S. Anti-staphylococcal plant natural products. Nat Prod Rep. 2004;21(2):263-267.

11. Ríos J, Recio M. Medicinal plants and antimicrobial activity. $J$ Ethnopharmacol. 2005;100(1):80-84.

12. Saleem M, Nazir M, Ali M, et al. Antimicrobial natural products: an update on future antibiotic drug candidates. Nat Prod Rep. 2010;27(2):238-254. 